\title{
Epistemological Dynamics and Incorporation of Appraisal Practices in Kampala Archdiocesan Secondary Schools
}

\author{
Muweesi Charles \\ Department of Education, Faculty of Science and Education, Busitema University, Busitema, Uganda \\ Email: cmuweesi@sci.busitema.ac.ug
}

How to cite this paper: Charles, M. (2018) Epistemological Dynamics and Incorporation of Appraisal Practices in Kampala Archdiocesan Secondary Schools. Open Access Library Journal, 5: e5052. https://doi.org/10.4236/oalib.1105052

Received: November 15, 2018

Accepted: December 24, 2018

Published: December 27, 2018

Copyright (c) 2018 by author and Open Access Library Inc.

This work is licensed under the Creative Commons Attribution International License (CC BY 4.0).

http://creativecommons.org/licenses/by/4.0/

\section{(c) (i) Open Access}

\begin{abstract}
Using selected secondary schools in Kampala Archdiocese, the study was intended to establish the appraisal practices used to assess teachers' performance in secondary schools in Kampala Archdiocese, Census and simple random sampling techniques were used to select the 196 respondents from a study sample population of 401 persons. Information was solicited through the use of face-to-face interviews with the head teachers and self-administered questionnaires which were distributed to teachers in the study area. Survey and questionnaire were used to collect data and after collecting data, descriptive statistics and percentages were computed with the help of SPSS computer package to analyze and facilitate discussion of findings. The study also found out that teachers are appraised; more than one performance appraisal method is used. It was concluded that among others, teachers' negative attitude towards the performance appraisal process is one of the difficulties which beset its conduct. The study recommended that among others, management ought to ensure that there is effective communication and information dissemination to teachers immediately after the performance appraisal is conducted, the appraisers ought to adopt a more cooperative approach during the appraisal exercise, get the full participation of teachers and change their attitude towards the performance appraisal process, and sensitization should also be intensified on the relevance and purposes of performance appraisal on improving teachers' performance.
\end{abstract}

\section{Subject Areas}

Education

\section{Keywords}

Appraisal Practices, Types of Appraisals, Ugandan Secondary Schools, 


\section{Introduction}

\subsection{Background to the Study}

Appraisal is the most common organizational source of recognition of performance and the basis for many important rewards [1]. All the activities comprising human resource management, performance appraisal is arguably the most continuous and least popular among those who are involved in it. Managers do not seem to like doing it; employees see no point in it, and human resource managers, as guardians of an organization's appraisal policy and procedures, have to stand by and watch their work fall into disrepute. However, despite the poor record of appraisal systems within organizations, it is an acceptable part of management that recommends that there should be some means by which performance can be measured, monitored and controlled [2].

Different reports from the different Kampala Archdiocesan education secretariats such as the catholic education secretariat 2014/15 indicate that most teachers do not want to be appraised. As a result, their non-academic performance (work other than teaching) is not known by the different stakeholders. This has constrained their performance both in class and outside class. Also from the teachers' expressions, there seems to be a link between carrying out appraisals and its main intention of changing teachers' attitude towards work. Those appraising mainly focus on the process of appraising rather than the outcomes of the appraisal exercise and this causes suspicion that the process is not done well. It was feared that if this trend of affairs is not checked, teachers may continue to negatively perceive the purpose of carrying out performance appraisals and this may adversely affect their output or work. Since it is acceptable that staff performance appraisal is a legitimate activity in organizations including secondary schools, there is need to get concerned with its effectiveness, fairness and its relationship with teachers' performance. This study therefore aimed at establishing the nature of appraisal practices used implicitically and explicitically in selected secondary schools Kampala archdiocese.

\subsection{Purpose}

The purpose of this study was to characterize the performance appraisal practices used in selected secondary schools in Kampala-Archdiocese.

\subsection{Theoretical Background}

For the purpose of this research, expectancy and goal setting theories were used. The Expectancy theory states that people are influenced by what they expect to be the impact of their actions. The theory was based on the assumption that human behavior is to some extent rational and individuals are conscious of their 
goals and motives and therefore it is possible to predict behavior. The theory attempts to measure the strength of the individual's performance based on motivation. [3] argues that managers need to realize that people work well only when they expect their efforts to produce good performance. Ideally managers have to establish clear procedures for evaluating levels of performance (appraisal) and give attention to intervening variables like abilities, traits, organizational procedures and support, which might affect performance albeit, indirectly. However, it's not yet established whether the appraisal practices in the catholic secondary schools in Kampala Archdiocese have clear procedures. Also the goal setting theory, [4] concluded that both situation factors and personality factors affect an individual's preference to work on easy or hard goals. Situation factors include success or failure on the tasks, monetary and verbal incentives, feedback, participation and competition. When employees participate in decision making, it increases their love to work and job satisfaction. [5] suggest that, participation is associated with employee satisfaction when it reduces role conflict and role ambiguity and clarifies the expectancy from performance to reward. Appraisal practices can be used to set out job objectives, provide information for human resource planning and career succession, assess the effectiveness of the selection process and as a reward or punishment in itself.

The theory was supported by [1] in essence, performance appraisal is both the regular formal and recorded review of the way in which individual staff is performing in his/her job. It could be conducted by immediate supervisor, or peers, using various techniques, hence the theory being adopted for this study.

\section{Review of Related Literature on the Concept of Appraisal Practices}

A lot of literature has been written on the subject of appraisal by different scholars of management. There are many definitions of staff appraisal as there are scholars of the same. [1] defined performance appraisal as the practice of evaluating individuals and teams by understanding and managing performance within an agreed framework of planned goals, standards and competence requirements. [6] defines appraisal as a systematic review of a persons' work and achievements over a recent period, usually leading to plans for the future. In this study, performance appraisal practices will be looked at in terms of types of appraisal. Each author attempts to describe what human beings are and what they can become.

[7], for example, defines appraisal as a method of reviewing and monitoring the appraises performance within a given time period and agreeing on courses of action for the future. Other management scholars such as [8] define performance appraisal to mean all formal procedures used in organizations to evaluate personalities in terms of their contributions and potentials.

The thinking behind the requirements to introduce formal appraisal systems had three elements, according to [9]. First is that, appraisal is a very common 
management technique in the commercial world of the 1980s and many key players in the determination of education policy at that time were impressed by the techniques of the business community. Secondly, appraisal of staff has a natural link to staff development. One cannot work without the other. Thirdly, appraisal offers management a way of relating rewards more closely to performance and contribution. However, many scholars including [10] observed that managers have long been reluctant to appraise subordinates. They note that in an activity as important as management of human resources, there should be no reluctance to measure predominance as accurately its one can. That is so because in almost all kinds of groups entering, whether in work or in play, performance and appraisal have usually been related in some way. Moreover, most people and particularly people of ability want to know how well they are doing. According to [11] the present verifiable objective or goal is the development of considerable potential.

\section{Types of Appraisal Practices Used in Organizations}

For many years employers have been evaluated against standards of personal traits. These may range from ten to fifteen personal characteristics such as ability to get along with people, leadership, analytical competence, industry, judgment and initiative. The list may also include such work-related characteristics as job knowledge, ability to carry through an assignment, production or cost results or success in seeing that plans and instructions are carried out [12]. However, there are practical problems of the trait approach to appraisal. This is because the valuation cannot be objective and as such employees who receive less than the top rating feel that they have been unfairly dealt with. Other scholars such as [13] have described trait criteria as vague and as such raters are dealing with a blunt tool, and have argued that subordinates are likely to be vague about what qualities they are hang rated on. He further argues that since the principle purpose of appraisal is to provide a basis upon which to plan for improvement, trait evaluation provides for tangible things to discuss, little on which participants can agree as facts and therefore little mutual understanding of what is required to obtain improvement.

According to [5], there are three kinds of performance appraisals that is, Comprehensive review, progress or periodic review and continuous monitoring. In the first place, appraisals should be conducted once a year with discussions frequently taking place. Other scholars such as [14] argue that a case should he made against and rigid schedule of appraisal performance reviews. It should be noted that there is no universally applicable time frame for the limit comprehensive review. It depends on the nature of the task, past company practices and other situational factors. They note that once twice or even three times may be appropriate for a particular organization or a person who is new in a job. Martin also argues that formal comprehensive reviews should be supplemented by frequent or periodic reviews; that is, observes that these reviews should be short, and relatively informal for purposes of keeping communication open between 
the superior and subordinates. Furthermore, priorities can be re-arranged and objectives can be renegotiable if warranted by changed situations. It is also certainly inappropriate to pursue absolute or even inappropriate objectives that were agreed upon in an environment of uncertainties. Continuous monitoring of performance works in such a way that when performance deviates from plan, one does it even wait for the next periodic review, instead the superior and the subordinate discuss the situation so that corrective actions can he taken at that time in order to prevent deviation from developing into a major problem.

Two categories of appraisal, namely the formal and informal appraisal are usually discussed. According to [15], informal appraisal is the continuous assessment of individual worker's performance by his /her superior or manager in the normal course of work. He says this kind of assessment is of an ad hoc nature and is as much determined by intuitive feelings rather than factual evidence of results. He adds that, it is a natural by-product of the day to day relationship between managers and subordinates. Formal appraisal on the other hand is a more rational and orderly means of assessing a worker. [15] urges that this type of appraisal involves assessment of an employee's performance in some systematic and planned way. It serves to determine how well an employee is working and decides on ways to improve performance. It therefore calls for an immediate feedback in order to be effective. [1] emphasizes that the importance of giving a timely feedback to an employee is to develop and maintain a motivated workforce. In 2001, a more detailed appraisal form was introduced by the ministry of public service and all head teachers were sensitized on how to use the instrument.

According to the appraisal instrument that is purported to be used now, areas that are measured include; personality behaviors, performance and achievement of goals. This is supported by [1], who argued that these are measured either quantitatively or qualitatively. Therefore, Taylor's view indicates that performance appraisal is a way of ensuring adequate performance. However, the accuracy and fairness of performance appraisal practices has become a serious concern in human resource management in institutions today. This is so, because organizations have become more competitive and more result oriented implying that the personalities working in these organizations need to be appraised not only for purposes of promotion and reward management, but more so in identifying areas of weakness to be improved and to raise the workers morale, especially by involving them in the appraisal programmes and giving them timely and regular feedback, thus compelling the researcher to seek for concerns in this study.

\section{Research Design}

The study employed a cross-sectional sample survey design which was largely descriptive and qualitative in nature. The study population included the different education stakeholders in secondary schools in the greater Kampala Archdiocese. It specifically targeted 196 schools within the same paradigm in Kampala 
Archdiocese metropolitan. It examined respectively, both private and government aided catholic secondary schools in Archdiocese. Of the accessible population of 401 teachers and head teachers of selected secondary schools in Kampala Archdiocese [16], Table of Sample Size Determination suggested minimum sample size of 196 respondents (186 teachers and chaplains and 10 head teachers) who were considered for this study.

\section{Response Rate}

The study targeted 196 respondents in collecting data with regard to appraisal practices and performance of teachers in catholic secondary schools in Kampala Archdiocese. The results for the response rate are presented in Table 1.

Results in Table 1 indicate that all the targeted respondents responded in time giving a response rate of $97 \%$. According to [17] a response rate of $50 \%$ is adequate for analysis and reporting; a rate of $60 \%$ is good and a response rate of $70 \%$ and over is excellent. Also [18] asserts that a response rate of $50 \%$ is adequate, while a response rate greater than $70 \%$ is very good. Based on these assertions, it implies that the response rate in this case of $97 \%$ is very good. This commendable response rate was made a reality after the researcher made personal calls and visits to remind the respondent to fill-in and return the questionnaires.

\section{Presentation, Analysis and Interpretation}

\section{Appraisal Practices Used to Assess Teachers' Performance}

The study was set to establish the appraisal practices used to assess teachers' performance in selected secondary schools in Kampala Archdiocese. A set of questionnaires and interviews were used to collect data from respondents. Using nine quantitative items, respondents were requested to do their self-rating basing on likert's scale ranging from 1 which represented strongly disagree, 2 represented disagree, 3 represented neutral 4 represented agree and 5 represented strongly agree. Table 2 gives pertinent results about this.

Table 2 shows that majority of the respondents (73\%) agreed when asked whether teachers in selected secondary schools in Kampala Archdiocese are appraised for their performance. On the other hand, only $26 \%$ disagreed when asked the same question. The fact that majority of the responses answered in agreement suggests that teachers in selected secondary schools in Kampala Archdiocese are appraised for their performance especially in government schools. However, results from interviews indicated that:

Table 1. Showing response rate.

\begin{tabular}{cccc}
\hline \multirow{2}{*}{ Selected sample } & \multicolumn{2}{c}{ Responses } & \multirow{2}{*}{ Response rate } \\
\cline { 2 - 3 } & Returned & Completed & \\
\hline 196 & 196 & 190 & $97 \%$ \\
\hline
\end{tabular}


Table 2. Responses regarding the appraisal practices used to assess teachers' performance.

\begin{tabular}{|c|c|c|c|c|c|c|c|c|c|c|c|c|}
\hline \multirow{2}{*}{ STATEMENT } & \multicolumn{2}{|c|}{ SA } & \multicolumn{2}{|c|}{ A } & \multicolumn{2}{|c|}{$\mathbf{N}$} & \multicolumn{2}{|c|}{ D } & \multicolumn{2}{|c|}{ SD } & \multicolumn{2}{|c|}{ TOTAL } \\
\hline & $\mathbf{F}$ & $\%$ & F & $\%$ & $\mathbf{F}$ & $\%$ & F & $\%$ & $\mathbf{F}$ & $\%$ & F & $\%$ \\
\hline $\begin{array}{l}\text { Teachers in this school are appraised } \\
\text { for their performance }\end{array}$ & 22 & 11.8 & 115 & 61.8 & 0 & 0 & 47 & 25.3 & 2 & 1.1 & 186 & 100 \\
\hline $\begin{array}{l}\text { The appraisers use more than one } \\
\text { type of appraisalmethods }\end{array}$ & 19 & 10.2 & 117 & 62.9 & 4 & 2.2 & 34 & 18.3 & 12 & 6.5 & 186 & 100 \\
\hline $\begin{array}{l}\text { Teacher appraisals are conducted on a } \\
\text { regular basis }\end{array}$ & 14 & 7.5 & 23 & 12.4 & 2 & 1.1 & 125 & 67.2 & 22 & 11.8 & 186 & 100 \\
\hline $\begin{array}{l}\text { There is a policy that guide appraisal } \\
\text { practices in this school }\end{array}$ & 12 & 6.5 & 15 & 8.1 & 10 & 5.4 & 100 & 53.8 & 49 & 26.3 & 186 & 100 \\
\hline $\begin{array}{l}\text { This school uses management by } \\
\text { objectives method to assess } \\
\text { performance of staff }\end{array}$ & 29 & 15.6 & 114 & 61.3 & 0 & 0 & 30 & 16.1 & 13 & 7.0 & 186 & 100 \\
\hline $\begin{array}{l}\text { This school uses self appraisal method } \\
\text { to assess performance of staff }\end{array}$ & 14 & 7.5 & 121 & 65.1 & 3 & 1.6 & 42 & 22.6 & 6 & 3.2 & 186 & 100 \\
\hline $\begin{array}{l}\text { This school uses appraisal interview } \\
\text { method to assess performance of staff }\end{array}$ & 5 & 2.7 & 6 & 3.2 & 137 & 73.7 & 35 & 18.8 & 3 & 1.6 & 186 & 100 \\
\hline $\begin{array}{l}\text { Appraisal practices in place undergo } \\
\text { regular review and improvement. }\end{array}$ & 8 & 4.3 & 35 & 18.8 & 0 & 0 & 124 & 66.7 & 19 & 10.2 & 186 & 100 \\
\hline $\begin{array}{l}\text { Performance appraisals assess the } \\
\text { employees' character, attitude, } \\
\text { potentials and past performance } \\
\text { on the job }\end{array}$ & 21 & 11.3 & 136 & 73.1 & 2 & 1.1 & 17 & 9.1 & 10 & 5.4 & 186 & 100 \\
\hline
\end{tabular}

Source: Field Research Findings. Key: (SD-Strongly Disagree, D-Disagree, N-Neutral, A-Agree, SA-Strongly Agree).

" $A$ lot of activities are done which could be elements of work assessment. These include signing in teachers attendance register, checking students work in books, marking of examinations as well as administering tests among others." (Interview on 22nd August 2015)

However, during an interview with one teacher from private schools urged that:

"Sometimes it was not necessary to appraise us in our private schools, because good academic results are enough to justify ones performance at work." (Interview on 22nd August 2015)

During the face to face interviews with the head teachers, the researcher was informed that the appraisal exercise in these schools was being conducted aiming at helping teachers to grow professionally, realize their weaknesses and further help them to overcome such weakness. Majority of the respondents (83\%) also agreed and only $14 \%$ disagreed when asked whether the appraisers use more than one type of appraisal methods. This implies that appraisers use more than one type of appraisal methods. However, when the researcher inquired whether these appraisals are conducted on a regular basis, only $20 \%$ agreed and the majority (79\%) disagreed. In an interview with one of the head teachers, she stated that:

"These appraisals are usually conducted at the end of the year and it depends 
on the institutional requirements at that time". (Interview on 11th August 2015)

Another teacher from a government aided school noted that:

"The appraisals are annually brought to us by the head teacher to be filled.

And when we ask why, we were informed that it is a requirement of the ministry of public service for all government employees to b appraised". (interview on 27 th August 2015)

However one head teacher during an interview still from a government aided school urged that:

"It's true that the appraisals are done once a year with forms issued by public service however, they are sent late and schools incur a lot of money photocopying these forms which affect our budget especially us in USE schools" (interview on 22nd August 2015)

In some other schools, the researcher found out that they were being conducted after two to three years. This therefore indicates that appraisals in these schools were not being conducted on a regular basis.

The researcher went ahead to establish the opinions of the respondents on whether there was a policy that guided appraisal practices in these schools or not. Results in Table 2 indicate that majority (80\%) of the respondents' opinions were in disagreement and only $15 \%$ of them agreed with this assertion. This suggests absence of policies guiding appraisal practices in these schools. The interviews also revealed the same findings. On the methods used in appraising teachers in selected secondary schools in Kampala Archdiocese. The results in Table 2 indicate that $77 \%$ of the respondents agreed about existence of management by objectives method and $73 \%$ agreed about existence of self appraisal method. This suggests existence of such appraisal methods in selected secondary schools in Kampala Archdiocese. On the other hand, majority of the respondents (74\%) were not sure about existence of interview method in these schools. This suggests limited use of the interview method in these schools.

When respondents were asked whether the appraisal practices in place undergo regular review and improvement, most of them (77\%) responded in disagreement and only 23\% agreed. This implies that the existing appraisal practices in selected secondary schools in Kampala Archdiocese do not undergo regular review and improvement. Nevertheless, results in Table indicate that majority (84\%) of the respondents' opinions were in agreement with the assertion that performance appraisals assess the employees' character, attitude, potentials and past performance on the job. Only $14 \%$ of the respondents disagreed with this assertion. This suggests that the performance appraisal practices in selected secondary schools in Kampala Archdiocese assess the teachers' character, attitude, potentials and past performance on the job.

From the above it is indicated that there are different appraisal methods used in appraising teachers in secondary schools. They are either formal, like the use of appraisal forms provided by ministry of public service in government schools or informally done like in private schools basing on agreed upon objectives and superior monitoring and assessment. 


\section{Discussion of Findings}

Responses from majority of the respondents revealed that teachers in selected secondary schools in Kampala Archdiocese were being appraised for their performance. This exercise aimed at helping teachers to grow professionally by enabling them express their concerns, realize their weaknesses and further helping them to overcome such weakness. This state of affairs agrees to what was put forward by [19] that the core of education is teaching and learning, which can only be achieved by having effective teachers. Effective teachers can only be seen when there are high quality evaluation systems. In addition, [20] stated that performance appraisal gives supervisors and employees the opportunity to review the performance standards and this is to identify their strengths and weaknesses in order to enable the supervisors design or recommend a specific programme that help employees improve upon their performance. It was observed from the study that performance appraisal would help appraisers identify good performing teachers as well as poor performing teachers and based on their quality of work and competence, promote or reward them.

Majority of the respondents also revealed that appraisers in selected secondary schools in Kampala Archdiocese use more than one type of appraisal methods. In support of this state of affairs, [6] stated that collecting information from multiple sources can increase the accuracy of performance evaluation (reduce bias), and increase employee's perceptions of fairness. The study further established that the most commonly used appraisal methods were management by objectives and self-appraisal methods. Nevertheless, most of the respondents (79\%) revealed that appraisals were not carried out on a regular basis. These findings contradict with what was suggested by Boice and Kleiner (2007) that performance reviews should be performed on a frequent and ongoing basis due to selective memory by the supervisor or the employee; and surprises at an annual review. [14] also stated that long interval between each appraisal and its contents lose relevance and risk artificiality. In addition, [21] found out that high quality teaching in schools would only be achieved when head teachers and heads of departments appraised their teachers on a regular basis to identify teacher weaknesses.

It was further revealed from the study that managers of selected secondary schools in Kampala Archdiocese did not conduct performance appraisal based on their strategic objectives as this was evident in the absence of a policy on the conduct of performance appraisal in these schools. Most of the respondents revealed that they have never heard or seen such policies in their schools. Absence of well written appraisal policies in these schools contradict with what was recommended by [7] who advocated for a well-designed appraisal policy since it can help achieve organizational objectives and enhance employee performance. Also [22] stated that absence of a clear cut policy on the conduct of performance appraisal imply that managers of schools do not attach any importance to the appraisal process and therefore not accountable to any authority notable for 
performance appraisal.

The study further revealed absence of regular review and improvement of the existing appraisal practices in selected secondary schools in Kampala Archdiocese. This state of affairs also disagrees to what was advocated for by [23] who stated that performance appraisal should be regularly reviewed and evaluated, especially in terms of their impact on performance and employee development. Nevertheless, results from majority of the respondents revealed that performance appraisals in selected secondary schools in Kampala Archdiocese where used to assess teachers character, attitude, potentials and past performance on the job as proposed by [24].

In further support of this [13] stated that performance reviews should give a view of how one has achieved intended goals by having a brief insight into what has been done perfect and what is still lacking in the performance requirements.

\subsection{Conclusions}

It's concluded that there are various performance appraisal practices used in Kampala archdiocese and they include self-appraisal, appraisal interviews and management by objective characterized with oral discussions with head teachers and chaplains though on rare basis. Others are written instruments to appraise teachers like those from ministry of public service.

The study identified that teachers in selected secondary schools in Kampala Archdiocese were being appraised for their performance with the major aiming at helping them to grow professionally, realize their weaknesses and further helping them to overcome such weakness. Such appraisals were usually conducted at the end of the year using management by objectives and self-appraisals methods. It was however noted that the different appraisal practices in these schools were not often reviewed for improvement and there were no policies written down to guide these appraisal practices. Nevertheless, the appraisals in selected secondary schools in Kampala Archdiocese were reported to be assessing teachers' characters, attitude, potentials and past performance on the job.

The study revealed that appraisers did not give feedbacks to teachers anytime when performance appraisal was conducted on their performances. It is therefore observed that there should be effective communication and information dissemination to teachers immediately after the performance appraisal is conducted. In this case, feedback should be promptly given and properly discussed with teachers, a move that would enable them to identify their strengths, weaknesses and the opportunities available for continuous improvement. This would also serve as a motivation to teachers who would in turn give off their best in their area of work. The appraisers should also endeavor to spell out what should be appraised, who should appraise and when will the appraisals be conducted.

\subsection{Recommendations}

The appraisers should also adopt a more cooperate approach during the appraisal exercise. Appraisals need not to be stressful or threatening as they are. In col- 
laboration with the appraisers, teachers should also be involved in setting performance goals and objectives. They need to be encouraged to identify their strengths and weaknesses; so that they can determine their key performance arrears (KPA's) and set goals for future performance.

Appraisers should be provided with training from human resources specialists to conduct appraisals of their teachers systematically and according to the philosophy of modern appraisal systems. To get the full participation of teachers and change their attitude towards the performance appraisal process, sensitization should also be intensified on the relevance and purposes of performance appraisal on their performance.

It is also recommends that each school in the study area develops a clear cut policy on the conduct of performance appraisal which would be in harmony with its strategic objectives. It is expected that this will make managers of schools accountable to any authority notable for performance appraisal.

The study recommends that different head teachers and the education secretariat should identify the possible challenges faced by the teachers' appraisers so as to create a better tool.

\subsection{Study Limitations}

Although the study was limited to appraisal practices, there are many other variables like, leadership styles, remunerations, delegation and communication all of which may affect performance of teachers in selected secondary schools in Kampala Archdiocese. Therefore future researchers may conduct studies to establish the contribution of any of these variables on performance of teachers in selected secondary schools in Kampala Archdiocese.

\section{Conflicts of Interest}

The author declares no conflicts of interest regarding the publication of this paper.

\section{References}

[1] Armstrong, M. (2002) Human Resource Management Practice: Theory and Practice. The Bath Press Ltd., Great Britain.

http://ebooks.bharathuniv.ac.in/gdlc1/gdlc4/MBA/eBooks/Handbook\%20of\%20HR M\%20Practice.pdf

[2] Barlow, H. (1989) Unspervised Learning \& Competition. MIT Journal of Education Practice, 45-56. http://mlg.eng.cam.ac.uk/zoubin/course03/lect7mcmc.pdf

[3] Porter, L.W. (1967) Competitive Strategy. Free Press, New York. https://www.ifm.eng.cam.ac.uk/research/dstools/porters-generic-competitive-strate gies/

[4] Cardy, R. (2004) Performance Management: Concepts, Skills and Exercises. Amonk, New York. https://lib.ugent.be/en/catalog/rug01:001807350

[5] Martin, R. (2000) Principles and Practices of Management. Konark Publishers PVT Ltd., New Delhi. 
[6] Muhammad, F. (2013) Role of Performance Appraisal System on Employees Motivation. Journal of Business and Management (IOSR-JBM), 8, 66-83. http://www.iosrjournals.org/iosr-jbm/papers/Vol8-issue4/H0846683.pdf

[7] Rudman, R. (2013) Human Resources Management in New Zealand. Pearson Education New Zealand Limited, Auckland. http://www.pearsoned.co.nz/9781486013661

[8] Yodder, D. (1998) Personal Principles and Policies. 2nd Edition, Prentice Hall Inc., Englewood Cliffs, NJ.

[9] Drucker, N. (1980) The Practice of Management. Heineman, London. https://www.amazon.com/Practice-Management-Peter-F-Drucker/dp/0060878975

[10] McGregor, D. (1960) The Human Side of an Enterprise. McGraw-Hill. New York. http://www.worldcat.org/title/human-side-of-enterprise/oclc/173969

[11] Hall, L. (2005) Personel Management: Human Resources Management Action. Prentice-Hall, Hertfordshire.

[12] Bitner, R. (2000) Career Development and Motivation in Organizations. Heineman, Butterworth.

[13] Decenzo, A. and Robbins, P. (2005) Personnel/Human Resource Management. Prentice Hall, India.

https://www.amazon.com/Personnel-Human-Resource-Management-Decenzo/dp/ 0136571980

[14] Morgan, G. (1988) Images of Organization. Sage Publication, Oxford. https://www.amazon.com/Images-Organization-Gareth-Morgan/dp/1412939798

[15] Cole, G. (1997) Personnel Management: Theory and Practice. 3rd Edition, Prentice, New Jersey.

https://www.abebooks.co.uk/book-search/title/personnel-management/author/ga-c ole/

[16] Krejcie, R.V. and Morgan, D.W. (1970) Determining Sample Size for Research Activities. Educational and Psychological Measurements, 30, 607-610.

https://journals.sagepub.com/doi/abs/10.1177/001316447003000308 https://doi.org/10.1177/001316447003000308

[17] Mugenda, O. and Mugenda, A. (2003) Research Methods: Qualitative and Quantitative Approaches. Acts Press, Nairobi.

https://textbookcentre.com/catalogue/research-methods-quantitative-and-qualitativ e-approaches_14788/

[18] Kothari, C.R. (2004) Research Methodology: Methods and Techniques. New Age International Publishers, Mumbai.

http://www.modares.ac.ir/uploads/Agr.Oth.Lib.17.pdf

[19] Stronge, J.H. and Tucker, P.D. (1999) The Politics of Teacher Evaluation: A Case Study of New System Design and Implementation. Journal of Personnel Evaluation in Education, 13, 339-359.

https://link.springer.com/article/10.1023/A:1008105332543 https://doi.org/10.1023/A:1008105332543

[20] Muwagga, A.M., Genza, G.M. and Ssemulya, R. (2013) School Leadership and Denominational Identity: The Case of Roman Catholic-Founded Schools in Uganda. American Journal of Educational Research, 1, 327-333.

http://pubs.sciepub.com/education/1/8/10/ https://doi.org/10.12691/education-1-8-10

[21] Muwanguzi, E. (2006) Appraisal System and Teacher Performance in Nansana. 
Makerere University Printery, Kampala, Uganda.

https://news.mak.ac.ug/documents/Makfiles/theses/Muwanguzi_Eria.pdf

[22] Adofo, P.S. (2011) An Evaluation of the Performance Appraisal System and Its Effect on Employee Performance: A Case Study of Selected Senior High Schools in the Kwahu-South District. Unpublished Master's (MBA) Dissertation, Kwame Nkrumah University of Science and Technology, Kumasi.

http://ir.knust.edu.gh/xmlui/handle/123456789/4441

[23] Türk, K. and Roolaht, T. (2005) A Comparison of the Appraisal Systems and Appraisal Compensation Interlinks used by Estonian Public and Private Universities. Tartu University Press, Tartu, Estonia.

https://majandus.ut.ee/sites/default/files/mtk/dokumendid/febawb41.pdf

[24] Mani, B. (2002) Performance Appraisal Systems, Productivity, and Motivation: A Case Study. Public Personnel Management. Journal of Public Management, 31, 141-159. https://journals.sagepub.com/doi/abs/10.1177/009102600203100202 https://doi.org/10.1177/009102600203100202 